\title{
Konstruksi Sufistik Pendidikan Multikultural Universitas Yudharta Pasuruan
}

\author{
Helmi Syaifuddin ${ }^{1}$, Rahmatullah Salis ${ }^{2}$, dan Ahmad Mahfudzi Mafrudlo ${ }^{3}$ \\ 1,2 Universitas Islam Negeri Maulana Malik Ibrahim Malang \\ ${ }^{3}$ STIES Gasantara Sukabumi
}

\begin{abstract}
The aim of this research is to comprehensively understand the sufistic construction and the construction patterns of Sufistic values in multicultural education. This study uses a qualitative method which stands on Peter L.Berger's social construction theory. The results of this study is that the construction, took place at the University of Yudharta Pasuruan was assisted by the vision and mission of the tertiary institution which became the perspective of the performance of the entire academic communities. On the other hand it is also based on understanding, awareness and transformation of knowledge. The dialectical entity of social construction theory runs perfectly, the entities are Externalization, Objectivation, and Internalization. Multicultural activities and behaviors are formed by and on the basis of mutually agreed understanding of religious texts, the teachings of the tarekat and the transformation of science in the classroom. The construction process which consists of habituation, institutionalization, and legitimacy helps the implementation of all multicultural behaviors and activities of the academics of Yudharta Pasuruan University
\end{abstract}

Keywords: Multicultural Education, Construction, Sufistic Values, Higher Education

\section{ABSTRAK}

Tujuan dari penelitian ini adalah untuk mengetahui secara comprehensive konstruksi sufistik dan pola konstruksi nilai-nilai sufistik dalam pendidikan multikultural.Penelitian ini menggunakan metode kualitatif berdasarkan teori konstruksi sosial Peter L.Berger. Hasil dari penelitian ini adalah bahwa konstruksi yang terjadi di Universitas Yudharta Pasuruan dibantu oleh visi misi perguruan tinggi yang menjadi cara pandang kinerja seluruh civitas akademika. Di lain hal juga didasarkan dari pemahaman, kesadaran dan transformasi ilmu. Entitas dialektika teori konstruksi sosial berjalan dengan sempurna, entitas tersebut adalah Eksternalisasi, Objektivasi, dan Internalisasi.Aktifitas dan perilaku multikultural terbentuk oleh dan atas dasar pemahaman yang disetujui bersama dari teks agama, ajaran tarekat dan transformasi ilmu di dalam kelas. Proses konstruksi yang terdiri dari pembiasaan, institusionalisasi, dan legitimasi membantu implementasi seluruh perilaku dan aktifitas multikultural para civitas akademika Universitas Yudharta Pasuruan.

Kata kunci: Pendidikan Multikultural, Konstruksi, Nilai-Nilai Sufistik, Perguruan Tinggi

\begin{tabular}{|c|c|c|}
\hline First Receive: & Revised: & $\begin{array}{c}\text { Accepted: } \\
\text { 25 June 2020 }\end{array}$ \\
\hline $\begin{array}{c}\text { Final Proof Recieved: } \\
\text { 28 June 2020 }\end{array}$ & 3 June 2020 & Published: \\
\hline \multicolumn{2}{|c|}{ 30 June 2020 } \\
$\begin{array}{c}\text { Syaifuddin, H., Salis, R., \& Mafrudlo, A. M., (2020). Konstruksi Sufistik Pendidikan } \\
\text { Multikultural Universitas Yudharta Pasuruan. Schemata, 9 (1), 1-14. }\end{array}$ \\
\hline
\end{tabular}

\section{PENDAHULUAN}

Populasi umat Islam dari segi jumlah belum bisa dilewati oleh negara yang dalam kajian kewilayahan disebut sebagai pusat studi Islam yakni Saudi Arabia.Sebagaimana dalam proyek dengan tajuk The Future of The Global Muslim Population : Projection for 2010- 
2030 dengan sajian data yaitu; di antara 10 negara-negara yang berpenduduk mayoritas Islam (Indonesia, Pakistan, India, Bangladesh, Mesir, Nigeria, Iran, Turki, Aljazair, Maroko), Indonesia, masih menurut Pew Research Center,3 menempati ranking teratas setidaknya sampai pada 2029.

Di balik keunikan dan heterogenitas Indonesia, masih teringat kondisi konflik horizontal pada tahun 2014 yang terjadi di Provinsi Maluku yaitu desa Luhu dan desa Iha. Bentrokan berdarah tersebut mengakibatkan 6 orang meninggal, 47 orang luka-luka dan dua gedung sekolah dibakar.Benrokan berdarah ini menambah panjang daftar konflik di Maluku. Sebelumnya konflik juga terjadi di Kabupaten Maluku Tengah, Kecamatan Leihitu, Desa Seith dan Lima menewaskan empat warga, belasan warga terluka serta 26 rumah di bakar masa. (Kompas, 5 Agustus 2014). Pada tanggal 7 Agustus 2014 juga terjadi tawuran dua kelompok warga di Tebet Jakarta Selatan, tawuran ini terjadi kesekian kalinya, bahkan warga khawatir akan berlanjut kembali. (Berita TVOne 7 Agustus 2014 jam 5.55 WIB). Di samping itu juga melanda lembaga-lembaga pendidikan, kekerasan yang dilakukan oleh oknum guru, tawuran antar pelajar dan siswa bahkan mahasiswa.Belum lagi bentuk-bentuk kriminalitas lainnya seperti teroris, pembunuhan, pelecehan seksual dan prahara lain-lain.

Dalam konteks Indonesia, globalisasi sudah tidak bisa dihindarkan dari anggota masyarakat. Ironinya dengan globalisasi banyak kasus yang yang terjadi di basis masyarakat plural yang harmoni. Problem-problem yang sering muncul di media masa didominasi oleh multikultural, contohnya adalah konflik intra dan antar umat beragama.Seperti yang ada dalam catatan nasional kompas, bahwa tindakan diskriminasi yang menjamur telah benarbenar menguji identitas keberagaman di Indonesia. Seperti yang ada dalam catatan yayasan Denny JA, dari jumlah kekerasan yang telah terjadi didominasi oleh latar belakang agama atau paham keagamaan dengan prosentase 65\%, kekerasan etnis $20 \%$, kekerasan jender $15 \%$ dan kekerasan orientasi seksual 5\%.

Tasawuf dengan nilai-nilai sufistiknya menawarkan beberapa hal yang bisa menjadikan konflik berkurang karena nilai teduh yang akhirnya menjadi harmonis.Diantaranya menjadikan hidup dengan husn al-Khatimah.Semua yang diciptakan oleh Allah tidaklah musuh tetap sebaliknya yaitu kawan menuju ke hidup yang lebih berarti dan bermanfaat.Untuk mengaplikasikan nilai-nilai sufistik tersebut diperlukan upaya transformatif, tentunya ada di pendidikan.

Pendidikan dirasa sangatlah penting untuk mengubah ranah konflik menjadi perdamaian.Paradigma pendidikan yang konstruktif diperlukan untuk membuka wawasan fikiran semua pihak untuk memberhentikan konflik-konflik yang telah terjadi.Pendidikan yang sangat dibutuhkan untuk pencerahan problem diatas adalah pendidikan multikultural.Dalam tataran praksis, konsep implementatif dari pendidikan multikultural belum bersifat holistik.Itu semua dikarenakan sebuah formalitas pemahaman keragaman atau diversitas dan terjebak merayakan keragaman secara parsial. 
Universitas Yudharta yang terletak di Pasuruan Jawa Timur, sangat terkenal dengan tradisi multikultural, tidak serta merta hanya menjadi jargon atau isu-isu implementasi konsep tersebut.Universitas Yudharta yang secara langsung didirikan sebagai bentuk perwujudan amal ibadah dari segi sosial Kyai Sholeh. Berangkat dari pemikiran dan kiprah transformative sang Kyai untuk membumikan multikulturalisme dibuatlah jargon untuk Universitas Yudharta yaitu "The Multicultural University".

Tarekat dengan nilai-nilai sufistik tidak serta merta hanya sebagai cerita kuno.Bahkan era kontemporer masih menjadi pijakan konseptual universitas Yudharta untuk memanifestasikan keaneka ragaman budaya, etnis, agama yang ada di Indonesia. Tentunya dengan usia UYP yang masih muda diharapkan selalu berkontribusi kepada seluruh rakyat Indonesia untuk mempertahankan NKRI. Sehingga penelitian dengan basis data multirkultural yang ditemukan sangat penting untuk dikaji.

\section{METODE PENELITIAN}

Kategori Penelitian ini merupakan kualitatif, yaitu penelitian yang menekankan pada proses sosial yang terjadi di lingkungan Universitas Yudharta Pasuruan. Proses yang terkait dengan implementasi multikulturalisme dengan basis konseptual nilai-nilai sufistik. Langkah dan solusi yang diberikan pihak kampus kemudian diimplementasikan bersama dengan akademisi kampus. Fokus penelitian ini ada di proses konstruksi nilai-nilai sufistik, maka penelitian ini termasuk jenis penelitian yang alamiah dan induktif.

Penelitian ini memakai pendekatan fenomenologi, Pendekatan ini mencoba memahami inti pengalaman dari suatu fenomena, dengan bertanya "apa pengalaman utama yang akan dijelaskan informan tentang subjek kajian penelitian". Karena itu langkahnya dimulai dengan ide filosofikal yang menggambarkan tema utama.

Setelah data yang sudah terkumpul dan fokus penelitian maka dilakukan analisis dengan teori kontstruksi realitas Peter. L. Berger. Teori yang tergolong dalam paradigma definisi sosial (the social definition paradigm) atau termasuk dalam kategori fenomena sosial bersamaan dengan teori proses mental, norma-norma, nilai-nilai, dan berbagai elemen budaya. Konstruksionisme yang dikembangkan oleh Peter.L.Berger tentunya disebut sebagai teori konstruksionisme sosial (social construction theory).

\section{HASIL DAN PEMBAHASAN}

\section{Akar Konsep Multikulturalisme: Melacak Spirit Pemahaman Multikulturalisme}

Diskursus gagasan multikulturalisme berawal menggema di Eropa dan Amerika. Lahir dari upaya memecahkan permasalahan hubungan antar rasial yang muncul di Amerika. Gordon menjelaskan, bahwa multikultural erat kaitannya dengan civil right movement (Gerakan hak-hak sipil) tepatnya tahun 1950 dan 1960. Gerakan tersebut adalah pertentangan terhadap dominasi Anglo-Saxon atau Eropa dalam bidang sosial politik dan 
ekonomi. ${ }^{1} \quad$ Lambert memperjelas bahwa pergeseran pemimpin merubah kondisi perpolitikan Eropa. Sang pemimpin Martin Luther King, Jr merevolusi gerakan hak sipil menjadi lebih baik sebagai sebuah negara demokrasi dimana semua masyarakat sipil dapat bergandengan tangan secara damai. ${ }^{2}$ Karena ketertarikan banyak akademisi, menjadi perbincangan menarik dan dijadikan alternatif ataupun koreksi terhadap model kebijakan pengelolaan pemerintahan. ${ }^{3}$

Berbagai macam pendapat dengan berbagai perspektif baik dari sisi antropologi dan sosiologi. ${ }^{4}$ Pertama: multikulturalisme adalah konsep yang menjelaskan dua perbedaan yang saling berkaitan (a) sebagai realitas kemajemukan dan pluralitas kebudayaan, berimplikasi kepada pemahaman akan toleransi (b) merupakan kebijakan pemerintah pusat yang telah dirancang guna memberikan perhatian penuh kepada kebudayaan dari seluruh kelompok etnis. Kedua: merupakan konsep sosial yang bisa diintroduksi ke dalam pemerintahan, sehingga nantinya bisa dijadikan kebijakan pemerintah. Ketiga: dilihat dari perspektif pendidikan, merupakan strategi pendidikan bagi seluruh elemen masyarakat untuk membentuk sikap multikultural. Dengannya akan terbentuk pemahaman kolektif atas kebudayaan, perbedaan budaya, keseimbangan dan demokrasi dalam arti luas. Keempat : merupakan bagian dari ideologi dengan harapan akan membentuk perilaku dan menjadi standar umum rakyat Indonesia. Semoga dapat mengarahkan seluruh rakyat ke dalam kehidupan masyarakat majemuk.

Dilihat dari kacamata antropologi Indonesia, Parsudi menjelaskan bahwa multikulturalisme adalah pengakuan dalam kesederajatan baik secara individual maupun kebudayaan. ${ }^{5}$ Azra menambahkan dalam tulisannya bahwa multikulturalisme didasari oleh pandangan dunia yang di follow up dari berbagai kebijakan kebudayaan yang tentunya menekankan pada keragaman budaya, pluralitas, dan kesadaran politik. ${ }^{6}$

\section{Tasawuf dan Masyarakat Multikultural}

Gulen, seorang teolog Turki yang sekaligus berlatarbelakang sufistik, memiliki konsep yang menitikberatkan kepada al-hub (cinta); yaitu cinta kepada Tuhan dan sesama manusia. Itu merupakan elemen yang sangat penting dalam eksistensi implikasi penciptaan

${ }^{1}$ Gordon,M.M, Assimilationin American Life: The Role of Race, Religionand National Origins (Oxfod University Press. New York 1964).

${ }^{2}$ Lambert, F. Religionin American Politics: A Short History (Princeton: Princeton University Press 2010).

${ }^{3}$ Yenny Zanuba Wahid, Dasar-Dasar Multikultural Teori dan Praktek. Pancasila Dan Sejumlah Tantangannya, (Yudharta Press Pasuruan, 2011) hlm 4

${ }^{4}$ Alo liliweri, Prasangka dan Konflik: Komunikasi Lintas Budaya Masyarakat Multikultural (Yogyakarta: LKiS, 2005), hlm 68-69.

5Parsudi Suparlan, Menuju Masyarakat Indonesia yang Multikultural, Antropologi Indonesia,no.69, (2002), hlm.100.

${ }^{6}$ Azyumardi Azra, Identitas dan Krisis Budaya, Membangun Multikulturalisme Indonesia, dalamhttp://snb.or.id/article/14/identitas-dan-krisis-budaya-membangun-multikulturalisme-indonesia , 24 Juli 2019) 
manusia ke dunia. ${ }^{7}$ Manifestasi dari cinta tersebut adalah hilangnya rasa derajat dan keunggulan jenis. Pandangan yang bersuber dari nilai-nilai tasawuf inilah yang kemudian menumbuhkan integrasi nilai sufistik dengan keharmonisan dan pemahaman multikltural.

Acapkali hal-hal sepele antara nilai-nilai ketuhanan di dikotomikan dengan sosial. Hal yang cacat atau tumpang tindih tersebut tidak akan berimplikasi kepada harapan multikultural. Sepadan dengan ungkapan Ibnu Arabi, multikultural termasuk konsep yang berimplikasi kepada keharmonisan.

God Himslef is the first problem of diversity that has become manifest in the cosmos. The fist thing that each existent thing looks upon is the cause of its own existence. In itself each thing knows that it was not, and then it then came to be through temporal origination. However, in this coming to be, the dispotions of the existent things are diverse. Hence they have diverse opinion about identity of causes that brought them into existence. Therefore the real is the first problem of diversity in the cosmos. ${ }^{8}$

Ungkapan diatas merupakan stimulus dan spirit yang telah ditemukan di unsur masyarakat multikultural khususnya bagi tokoh - tokoh masyarakat yang menjadikan masyarakat bimbingannya memahami spirit pluralitas.

Kesimpulannya adalah bagaimana esensi tasawuf yang terintegrasi dalam diri masyarakat multikultural.Perilaku baik atau berbuat ke semuanya diibaratkan seperti air hujan yang menyirami ke segala sesuatu di muka bumi.

\section{Nilai- Nilai Sufistik Pendidikan Multikultural}

Keunikan tasawuf adalah milik Islam. Untuk membedakan antara mistisisme yang dimiliki oleh Islam dengan agama lain, doktrin-doktrin sufi memiliki derajat universal khususnya pada kemanusiaan karena tasawuf adalah moral. ${ }^{9}$

Said Aqil Siraj berpendapat bahwa tasawuf tidak hanya sebagai metode pasif dan apatis terhadap realitas, bahkan kontributif terhadap semuanya.Sifat dari kontribusi tasawuf bukan terletak pada teori, tetapi memberikan aspek yang bisa menggerakan tangan dan kaki untuk berbuat lebih baik. ${ }^{10}$ Dr. Abu 'Ala al-afifi menambahkan bahwa tasawuf berperan besar dalam mewujudkan revolusi spiritual. Dalam hal ini yang berperan dominan untuk revolusi spiritual adalah pendidikan.Aspek tersebut ada basis dasar dari akhlak yang ada dalam substansi tasawuf.Sehingga kebutuhan masyarakat kepada tasawuf tidak bersifat nihil tanpa hasil.Karena di dalamnya ada bimbingan manusia dalam menyikapi keharmonisan dalam bergaul dan berkomunikasi dengan sesama. ${ }^{11}$

\footnotetext{
${ }^{7}$ Fethullah Gulen, Toward Global Civilization; Love and Tolerance, (New Jersey : Light, 2004) hlm.1

${ }^{8}$ Ibnu Araby, al-Futu $>$ ha $>$ t al-Makkiyah, Mahmu $>$ d Matraji $>$ (ed), 8 volume (beirut :Da $>$ r al-Fikr, 2002) vol. VI hlm. 303

${ }_{9}^{9}$ Moch.Tijani Abu Na'im, Sufisme Sebagai Prinsip Moralitas Universal: Sebuab Tinjauan Historis Atas JejakJejak Damai Kau Sufi, (Tashwirul Afkar; Jurnal Refleksi Pemikiran Keagamaan dan Kebudayaan, 2013)h. 95

${ }^{10}$ Said Aqil Siraj, (2002), Pendidikan Sufistik di era Multikultur dalam Republika, 21 Juni 2003.

${ }^{11}$ Said Aqil Siraj, (2002), Pendidikan Sufistik di era Multikultur dalam Republika, 21 Juni 2003. 
Temuan Alwi Shihab menguraikan bahwa tarekat merupakan mediapaling efektif dalam mendakwahkan Islam seperti telah dilakukan oleh para Wali, khususnya Wali Songodalam usahanya melakukan proses awal islamisasi di Indonesia, atau, secara lebih terbatas Islam di Jawa, Sulawesi dan Sumatera. ${ }^{12}$

Implementasi multikultural di ranah pendidikan berimplikasi kepada pemahaman dan perilaku yang toleran, melihat perbedaan tanpa ada rasa emosi ataupun anarkis.

\section{Universitas Yudharta Pasuruan dan Sistem Pendidikan Multikultural}

Dalam UU. SISDIKNAS No.20 tahun 2003 pasal 4 ayat 1 yaitu "pendidikan diselenggarakan secara demokratis dan berkeadilan serta tidak diskriminatif dengan menjunjung tinggi hak asasi manusia, nilai keagamaan, nilai kultural dan kemajemukan bangsa". Undang-undang Sisdiknas tersebut sebagai indikator perhatian pemerintahan kepada seluruh rakyat Indonesia.

Sebagai sebuah institusi pendidikan tinggi yang bernaung di yayasan pesantren, Universitas Yudharta Pasuruan tidak serta merta mengikuti stigma yang berkembang bahwa pendidikan pesantren hanya memperlihatkan frame pendidikan agama dan tidak akan menyentuh urusan luar.Pendidikan multikultural di institusi pendidikan tinggi merupakan solusi yang tepat untuk pendidikan bangsa Indonesia.Atas dasar itulah Universitas Yudharta Pasuruan (UYP) menetapkan visinya menjadi Universitas yang unggul dengan bingkai moralitas religius multikultural.Tentunya dengan berbagai kegiatan kampus yang terarah ke multikultural.Indikasi dari itu semua dapat dilihat di pola kurikulum yang terbentuk.

\section{Landasan Pendidikan Multikultural di Universitas Yudharta Pasuruan}

\section{Perintah Al-Qur'an dan Hadits}

Ayat Al-Qur'an berbunyi: "Hai manusia, Sesungguhnya Kami menciptakan kamu dari seorang laki-laki dan seorang perempuan dan menjadikan kamu berbangsa - bangsa dan bersuku-suku supaya kamu saling kenal-mengenal. Sesungguhnya orang yang paling mulia diantara kamu disisi Allah ialah orang yang paling taqwa diantara kamu. Sesungguhnya Allah Maha mengetahui lagi Maha Mengenal".

Proses kedamaian yang dimulai dengan komunikasi baik, interaksi baik, dan ihsan kepada seluruh makhluk Allah menghasilkan keadaan masyarakat yang multikultural. Proses menuju kedamaian tersebut tanpa ada alasan bahwa obyek yang ada dalam komunikasi dan berbuat baik tidak memandang apakah memiliki kulit yang berbeda atau percaya kepada agama yang berbeda. Inilah landasan konseptual urgensi komunikasi, interaksi dan berbuat Ihsan dalam perspektif Islam.

${ }^{12}$ Lihat Alwi Shihab, Islam Sufistike "Islam Pertama dan Pengarubnya di Indonesia,(Bandung: Mizan, 2001) Cet. I., h. $18-24$ 


\section{Ajaran Tarekat}

Sebagai jamaah tarekat Naqshabandiyah, idealnya adalah melakukan perintah dari mursyid tarekat. Sebagai pimpinan Pondok Pesantren Ngalah, yang juga sekaligus representasi dari civitas akademika Universitas Yudharta Pasuruan yaitu Kyai Sholeh. Beliau memiliki misi untuk berideologi dan mengamalkan Islam Abl al-Sunnah wa al-Jama'ah. Itulah amalan tarekat Naqshabandiyah yang sudah diterima dari guru-guru beliau.

Ajaran yang sering ditekankan khususnya dalam hal pluralitas kepada para jamaah tarekat adalah harus berbuat baik kepada semua manusia dan kepada semua makhluk Allah.

Sebagai seorang mursyid, Romo kyai selalu dawuhi kepada kami jamaah tarekat yang sudah beliau baiat. Salah satu rukun nomor lima dan enam di tarekat Naqshabandiyah itu mbagusi kabeb konco lan mbagusi kabeh makhluk. Ini misi tarekat, ini termasuk berbuat ihsan ${ }^{13}$

Selain itu Mursyid Romo Kyai Sholeh menambahkan, semua lembaga pendidikan disini punya prinsip Ngayomi lan Ngayemi. Sebagai ulama sufi dalam bermasyarakat dan bernegara seluruh jamaah tarekat tidak boleh membanding-bandingkan satu orang dengan lainnya. Idealnya ulama sufi adalah tiang sepub tur nyepui, lan madangi (tua dan mampu berjiwa tua serta menjadi penerang bagi yang lainnya). ${ }^{14}$

\section{Kurikulum}

Pengejawantahan dari visi misi kemudian diimplementasikan oleh kurikulum yang notabene adalah acuan dasar seluruh kegiatan dan sentralisasi tangan, kaki para civitas akademika di Universitas Yudharta Pasuruan (UYP).Kurikulum yang berbasis pada landasan multikultural terbangun dari perintah yang secara langsung tertulis dalam visi dan misi yayasan dan perguruan tinggi.

Kurikulum Multikultural yang dibuat dengan memperhatikan beberapa indikator berikut; Pertama, Bangsa Indonesia menganut sebuah prinsip falsafah yang majemuk, yaitu bhineka tunggal ika.Kedua, Pluralistas adalah nafas dari kebhinekaan.Dan kehidupan yang bhineka tidak dapat tercermin tanpa adanya pemahaman keberagaman.Ketiga, Visi dan Misi Universitas Yudharta Pasuruan yang bernafaskan multikultural.Keempat, Masih terdapatnya dosen-dosen pengampu mata kuliah dasar-dasar multikultural yang tidak seirama dalam penyampaian materi.Kelima, adanya kesulitan mengintegarasikan konsep multikultural di beberapa mata kuliah di semua proram studi Universitas Yudharta Pasuruan (UYP). Maka, UYP bekerjasama dengan DIKTI dalam pengelolaan dana PHP-PTS mengadakan workshop pengembangan kurikulum berbasis lokal berkarakter multikultural selama dua hari pada tanggal 16-17 september 2013. ${ }^{15}$

Perumuskan kurikulum multikultural baik yang bersifat eksplisit maupun implisit, dapat diterapkan ke dalam tiga mata kuliah yakni; dasar-dasar multikultural, kewarganegaraan dan bahasa Indonesia.Selanjutnya pengintegrasian nilai-nilai multikultural

${ }^{13}$ Wawancara dengan Dr. M.Anang Sholihuddin, S.Pd.I, M.Pd.I pada tanggal 23 Juli 2019

${ }^{14} \mathrm{Ibid}$

${ }^{15}$ Data diambil dari BAAK UYP pada 30 Juli 2019

Copyright (C) 2020 Schemata Journal

Available online at http://journal.uinmataram.ac.id/index.php/schemata 
disusun dalam silabus mata kuliah dan kurikulum setiap prodi, ${ }^{16}$ sehingga bisa tercapai keseragaman capaian pembelajaran sesuai dengan visi-misi universitas.Dan salah satu bentuk indikator kurikulum yang bisa dilihat setiap harinya oleh civitas akademika adalah ada beberapa nama di gedung kampus bernafaskan ruh pluralitas dan multikulturalisme.

\section{Konstruksi Sufistik Universitas Yudharta Dalam Pendidikan Multikultural}

\section{a. Proses Pembiasaan Multikulturalisme di Perguruan Tinggi}

Proses paling utama dalam habitualisasi multikultural di lingkungan kampus UYP adalah bagaimana menerapkan ibsan terhadap semua manusia. Akan ditemukan banyak keterbukaan ketika melaksanakan konsep ihsan di setiap langkah bermuamalah. Hal tersebut tidak lepas dari syarat dan rukun tarekat yaitu kewajiban untuk berbuat baik kepada sesama manusia dan makhluk Allah. Perwujudan konsep ihsan tersebut dapat ditemukan ketika melakukan silaturrahim ke Universitas Yudharta Pasuruan. Seluruh Civitas Akademika UYP tidak membeda-bedakan beberapa tamu yang berkunjung ke kampus. ${ }^{17}$ Inilah penerapan metode dakwah yang dilandasi oleh sikap ihsan kepada sesama makhluk Allah. Semua manusia adalah teman atau saudara sendiri.

Salah satu implikasi pembiasaan multikultural di kampus UYP ini adalah sebagai dasar penyusunan RENSTRA 2010 - 2015 atau dengan satu kebijakan pengembangan disiplin ilmu yang multikultural. ${ }^{18}$ Proses habitualisasi multikultural dengan landasan konseptual sufistik diharapkan menjadi pondasi dalam memperkuat serta mewujudkan Universitas Yudharta memiliki keunggulan yang multikultural.

\section{b. Proses pelembagaan Multikulturalisme sufistik di Perguruan Tinggi}

Hasil dari konstruksi sufistik pendidikan multikulturalisme yang telah di lakukan dalam pendidikan formal perguruan tinggi adalah bahwa proses institusionalisasi multikultural dianggap sudah sangat matang adanya. Seluruh mahasiswa dan khususnya civitas akademika Universitas Yudharta Pasuruan (UYP) tidak perlu terus menerus diingatkan bahwa multikulturaslime menjadi hal yang ada dalam landasan setiap individu.

Melalui institusionalisasi ini semua civitas akademika termasuk mahasiswa telah melaksanakan teori dasar-dasar multikultural. Pemahaman akan dasar multikultural tersebut menjadi landasan di setiap perilaku sosial antara manusia ( hubungan antar manusia beragama). Mereka membentuk kultur masyarakat beragama, bahkan membuat kultur yang khas sehingga secara sosiologis sering muncul dalam interaksi sosial antar umat beragama.

\footnotetext{
${ }^{16}$ Data diambil dari silabus integrasi multikultural terhadap mata kuliah dasar-dasar multikultural, bahasaIndonesia dan kewarganegaraan pada 20 Juli 2019

${ }^{17}$ Wawancara dengan ketua KPPS Universitas Yudharta Pasuruan, 25 Juli 2019

${ }^{18}$ Wawancara dengan ketua KPPS Universitas Yudharta Pasuruan, 25 Juli 2019 


\section{c. Proses Melegitimasi Substansi Multikulturalisme di Lingkungan Universtas Yudharta Pasuruan}

Institusionalisasi memerlukan sebuah legitimasi dengan cara-cara tertentu. Tentunya dengan komunikasi dan simbol-simbol yang ada di sekitar realitas. Simbol yang banyak ditemukan salah satunya adalah dengan nama-nama gedung yang khusus diberikan dengan simbol khas keIndonesiaan, seperti Gedung Pancasila, Gedung NKRI dan lain-lainnya.

Nilai-nilai institusionalisasi sufisme lebih dominan kepada kebijakan multikulturalisme di tingkat perguruan tinggi. Terlebih kondusifitas lingkungan sekitar yang telah terbangun sedemikian rupa, sehingga nampak tidak ada hambatan dalam proses habitualisasi, institusionalisasi dan legitimasi multikultural yang lebih sufistik. Landasan sufistik lebih diambil oleh komunitas di perguruan tinggi karena tidak jauh beda dengan apa yang sudah diutarakan oleh setiap individu.

\section{Konstruksi Sosial Pendidikan Multikultural di Universitas Yudharta Pasuruan}

\section{a. Eksternalisasi}

Pada tahap awal yaitu eksternalisasi merupakan sebuah proses utama bagi lahirnya produk sosial. Produk sosial dan ritual dari aktivitas manusia pada momentun eksternalisasi dapat diamati melalui bahasa dan tindakan lainnya berdasarkan penafsiran - penafsiran subyektif. Artinya seluruh aktivitas yang telah dilakukan tidak datang tiba-tiba, melainkan memiliki landasan normatifnya yang tentunya berkaitan dengan nilai-nilai keagamaan.

Landasan normatif disini menjadi signifikan dan erat kaitannya dengan sosiologi kultural individu atau pelaku. Ini semua dapat dilihat bahwa civitas akademika melakukan kegiatan atau tindakan multikultural tidak bisa lepas dari landasan normatif. Semua tindakan disesuaikan dengan mencari dasar legitimasi yang bersumber dari teks-teks normatif. Teks tersebut dapat ditemukan di dalam Al-Qur'an, Hadith dan pendapat ulama-ulama. Salah satu contoh teks normatif tersebut dapat ditemukan di buku Kyai Sholeh berjudul "Jawabul masail' , buku-buku karya dosen sendiri ataupun dari tulisan para pakar dan ilmuwan Indonesia dan barat. Di lain hal para mahasiswa banyak terpola pemahaman pendidikan multikultural dengan cepat dari apa yang sudah mereka pelajari dari kitab klasik yang menjadi konsumsi keseharian mereka selain berstatus mahasiswa mereka juga menjadi santri Pondok Pesantren Ngalah.

"sebenarnya saya ini disini banyak mendapatkan ilmu. Dimulai dari ilmu " nggowo awak", ilmu fiqh, ilmu tasawuf khususnya tentang tarekat Naqshabandiyah. Disitu saya menemukan banyak hal salah satunya landasan dan sumber memahami multikultural. Kabeh wong nang ndunyo ciptaane gusti Allah la lapo kok gak gelem mbagusi utowo serawung nang konco liane (seng gak podo agamane)"19

Inilah sebuah kontekstualisasi pendidikan multikultural bagi seluruh civitas akademika. Memperoleh dasar legitimasinya dari teks normatif atau nilai lama yang

${ }^{19}$ Wawancara bersama mas roziq pusat konveksi Pondok tanggal 23 Juli 2019 
tertanam di dalam tradisi masyarakat. Tindakan multikultural tersebut senantiasa membawa manfaat bagi semuanya dan dengan satu tujuan untuk semuanya.

Efek dari semuanya adalah mereka (beberapa subyek) dapat mengubah pola dan sistem di lingkungan kampus sesuai kehendaknya. Fenomena realitas sosial menurut Berger dan Luckman termasuk kategori eksternalisasi, karena masyarakat adalah produk manusia. ${ }^{20}$ Beberapa kecenderungan tersebut dinilai wajar sebab nilai-nilai sosiologi kultur yang merealisasikannya.

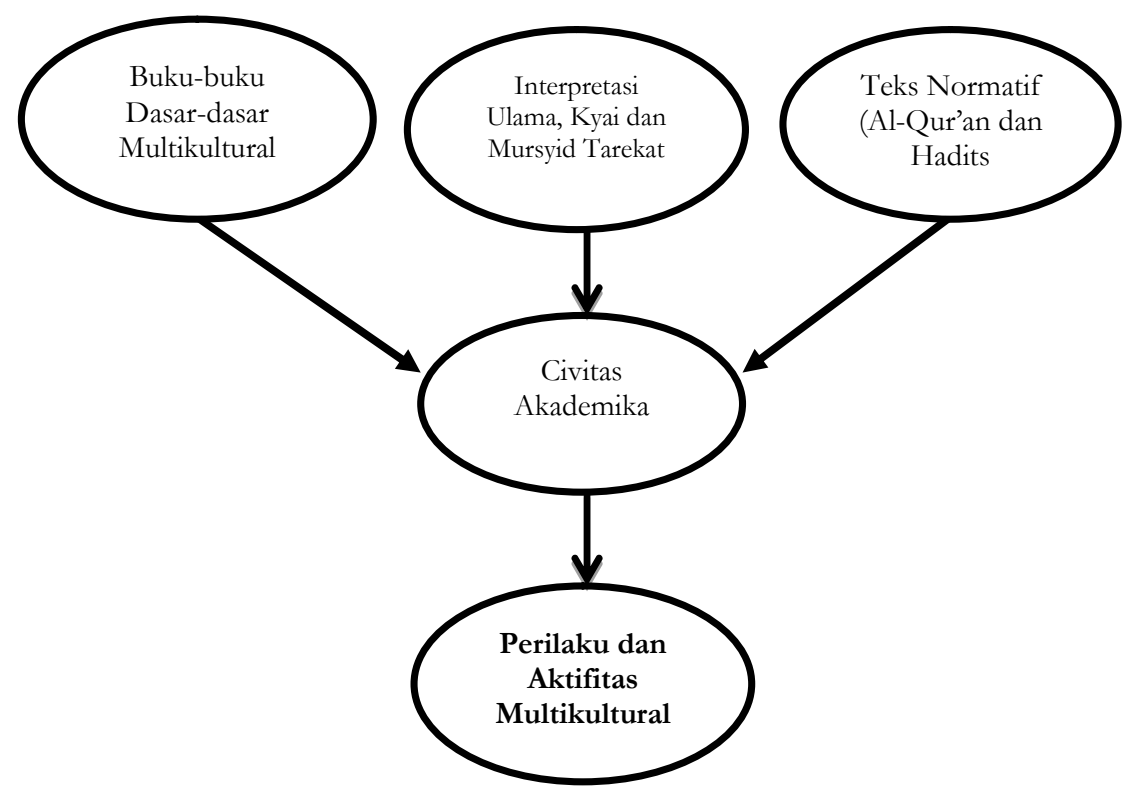

Gambar 1. Pembentukan Perilaku dan Aktifitas Multikultural

\section{b. Objektivasi}

Objektivasi adalah produk dari aktivitas atau hasil dari pergumulan eksternalisasi. Sederhananya, produk sosial yang dihasilkan dari proses eksternalisasi akan terbentuk realitas sosial lain (fakta-fakta) yang ada dalam diri pelaku. ${ }^{21}$ Inilah momen adanya interaksi sosial di dalam intersubyektif yang diinstitusionalisasikan. Dapat dilihat dari produk atau hasil fisik yang dicapai. Dengan maksud, bahwa proses eksternalisasi menyebabkan munculnya sesuatu yang berdiri sendiri antar individu. Menjadi entitas diluar individu bahkan memiliki perbedaan antara satu individu dengan lainnya.

Keputusan para civitas akademika mengikut dengan tanpa beban menjadi bukti kongkrit bahwa diluar kondisi tertekan mereka tidak merasakannya. Itulah efek positif proses interaksi dan komunikasi antar individu yang tidak lepas dari simbol-simbol framing yang bisa difahami dan dipelajari bersama. Lalu pilihan untuk terbuka (inklusif),

${ }^{20}$ Peter L Berger. \& Thomas Luckmann 1994. Langis Suci: Agama... hal 18

21 "objectivation is the attainment by the products of this activity (again both physical and mental)of a reality than confront its original producers as a facticity external to and other than themselves" lihat di Peter L. Berger, The Social Reality... hal 14

\section{Copyright @ 2020 Schemata Journal}

Available online at http://journal.uinmataram.ac.id/index.php/schemata 
toleran dan berbuat ihsan kepada siapapun didasarkan atas keyakinan bersama yang terbentuk dari proses habitualisasi, institusionalisasi dan legitimasi.

Nilai-nilai sakral sufisme yang terpolarisasi dalam diri civitas akademika sekaligus menjadi landasan dan pedoman dalam bertindak dimanapun dan kapanpun. Sehingga terbentuklah apa yang bisa disebut dengan pelembagaan (institusionalisasi).

\section{c. Internalisasi}

Internalisasi adalah penyerapan kembali dan pentransformasian realitas tersebut dari struktur-struktur obyektif kedalam kesadaran subyektif. Pemahaman sederahananya adalah beralihnya realitas obyektif ke realitas civitas akademika di Universitas Yudharta Pasuruan.

Momen internalisasi merupakan aktivitas masyarakat menyerap kembali sebuah realitas yang telah terbentuk sebelumnya. ${ }^{22}$ Proses penyerapan terebut mengharuskan kepada masyarakat untuk dilakukan langsung oleh masyarakat, kemudian ditransformasikan dari struktur dunia ke dalam struktur kesadaran subyektif.

Contoh empiris dari momen internalisasi tersebut adalah ketika seseorang dari civitas akademika UYP telah merespon makna-makna di realitas multikultural yang berasaskan sufisme, kemudian akan terjadi proses penegasan dalam kesadaran secara subyektif (personal). Sosialisasi yang telah terjadi merupakan upaya pentransformasian pengetahuan tentang makna-makna tertentu dari satu generasi ke generasi berikutnya.

Dalam hal ini momen konstruksi sosial perlu melibatkan sosok representatif ataupun mereka yang telah melakukan transformasi multikultural (sosok Kyai dan dosen), menjadikan eksistensi kesepakatan kolektif terjaga. Dan proses konstruksi yang telah menjadi idealitas an sich tidak berubah begitu saja. Hal tersebut bertujuan agar menjaga keberlangsungan nilai-nilai realitas obyektif yang telah terbangun. Bila melihat model pengembangan integratif pendidikan sufistik ke dalam pendidikan multikultural maka orang yang berpengaruh seperti Rektor, Kaprodi kepala bagian, dosen ataupun kepala bidang kepegawaian berperan penting dalam menjaga eksistensi model integratif pendidikan multikultural yang berasaskan sufisme.

Setelah hal tersebut terimplementasikan dengan baik berdampak pada tambahnya simpati seluruh civitas akademika. Di lain hal akan memudahkan proses internalisasi sekaligus kepada subyektifitas individu.

Kesimpulannya, dalam momen internalisasi ini terdapat penyerapan kembali sakralitas yang ada dalam pendidikan multikultural yang berbasis sufisme.

\section{KESIMPULAN}

Universitas Yudharta Pasuruan merupakan institusi pendidikan yang berpedoman pada idealitas apa yang telah direncanakan. Segala sesuatu yang sudah direncanakan adalah

${ }^{22}$ Peter L. Berger, The Social Reality... hal 14

Copyright (C) 2020 Schemata Journal

Available online at http://journal.uinmataram.ac.id/index.php/schemata 
titik poin dari apa yang harus dilakukan. Hal itulah yang menjadikan slogan kampus multikultural terimplementasikan secara maksimal. Idealitas tersebut ditopang oleh basis cara pandang para civitas akademika yang telah sejalan dengan visi dan misi kampus. Hal tersebut menjadikan kampus multikultural tidaklah sesulit yang dibayangkan.Jiwa-jiwa sufistik yang telah dipelajari dari teks normative, ajaran tarekat dan transformas ilmu (knowledge transformation) menjadi landasan konseptual dan implikasi ruh multikulturalisme.

Pendidikan multikultural di Universitas Yudharta Pasuruan telah terkonstruk dengan menggunakan kacamata agama dan tarekat.Dalam kacamata agama firman Allah menjelaskan pluralitas ciptaanNya sehingga itulah bahasa representasif bagi para civitas akademika Universitas Yudharta Pasuruan.Dalam kacamata tarekat dilihat dari seluruh akademisi UYP adalah mayoritas pengikut dan pemerhati tarekat (meskipun tidak sebagai pengikut yang sudah dibaiat, karena tidak seluruh civitas yang beragama Islam).

Aktifitas multikultural di Universitas Yudharta Pasuruan terbentuk dari setiap individu (civitas akademika) yang disadari dengan keinginan tertentu didukung oleh teksteks suci, ajaran ideologis tarekat Naqshabandiyah Mujadidah Kholidiyah, buku-buku yang ditransformasikan atau dibaca oleh setiap peserta didik.

Perilaku multikultural civitas akademik Universitas Yudharta Pasuruan terbentuk dari kesadaran setiap individu.Didasari oleh ajaran normative yang dipelajari, dibantu oleh dialektika antar individu di lingkungan kampus. Kesadaran mereka akan multikulturalisme membentuk perilaku keseharian untuk menganggap bahwa seluruh manusia harus membentuk sosialisasi yang terbaik. Unsur pemahaman tarekat yang mereka pegang bahwa "assufi kassama'i wa assufi kalmathori”yang artinya sufi seperti langit dan sufi seperti hujan.

\section{DAFTAR PUSTAKA}

(1990) The Consequences of Modernity, Cambridge: Polity Press.

Abu-Na'im, \& Tijani, M. (2013). Sufisme Sebagai Prinsip Moralitas Universal: Sebuah Tinjauan Historis Atas Jejak-Jejak Damai Kau Sufi, Tashwirul Afkar; Jurnal Refleksi Pemikiran Keagamaan dan Kebudayaan

Amstrong, K., (2009). Masa depan Tuban, Bandung: Mizan.

Arifin, S. (2014), Multikulturalisme Dalam Skema Deradikalisasi Paham Dan Gerakan Keagamaan Radikal Di Indonesia, Makalah AICIS Balikpapan

Banks, J.A, (1986). Multicultural Education: Development, Paradigms and Goal. InJ. A. Banks \& J.Lynch(Eds), Multicultural Education in Western Societies. London: Holt, Rinehart and Winston

Bikku-Parekh dalam Lucia Ratih Kusuma Dewi“ kembalinya Subyek : sosiologi memaknai kembali multkulturalisme" jurnal sosiologi masyarakat. hlm.74

Bogdan, R. C. \& Sari K.B., (1998). Qualitative Research for Education: An Introduction to Theory and Methods, London: Allyn and Bacon.

Creswell, J.W. \& Ahmad, A. L. (2014) Penelitian Kualitatif dan Desain Riset. Yogyakarta: Pustaka Pelajar.

Denzim, N. K. \& Yvonna, S. L., (1994). Handbook of Qualitative Resarch. California: Sage Publication.

Fedyani, (1995), Agama: Dalam Analisa dan Interpretasi Sosiologis, Jakarta:Raja Grafindi Persada 
Ghufron, MN. (2002). Mencari Format Pendidikan Agama yang Inklusif. Majalah Depag, Rindang Edisi Januari

Gidden, A., (1993) Sosiology, Cambridge: Polity Press

http://nasional.kompas.com/read/2012/12/23/15154962/Lima.Kasus.Diskriminasi.Terb uruk.Pascareformasi. Diakses 05-09-2018

Kimball, C., (2013) When Religion Become Evil terj. Nurhadi dan Izzudin Wasil. Bandung : Mizan

Maksum, A., (2011) Pluralisme dan Multikulturalisme Paradigma Baru Pendidikan Agama Islam di Indonesia, (Malang dan Yogyakarta, Aditya Media Publishing, 2011)

Miles, M. B. Miles, \& Hubermen, (1992). Analisis Data Kualitatif terj. Tjetjep, Rohadi, Jakarta: UI Press

Moleong, L. J. (2002). Metodologi Penelitian Kualitatif. Bandung: Remaja Rosdakarya.

Nasution, S., (1996). Metode Penelitian Naturalistik-Kualitatif. Bandung: Tarsito

Ritzer, G., (1996), Sociological Teory, $4^{\text {th }}$ Edition. Singapore: he McGraw-Hill Companies.

Said Aqil Siraj, (2002), Pendidikan Sufistik di era Multikultur dalam Republika, 21 Juni 2003.

Said, M. (2015), Rethinking Islamic Theology, Mengagas Teologi Sosial dalam konteks Pluralisme dan Multikulturalisme (Persfektif Pemikiran Teologi Fethullah Gulen), Makalab AICIS 2015

Shihab, A. (2001) Islam Sufistik. 'Islam Pertama dan Pengarubnya di Indonesia, Bandung: Mizan

The Pew Research Center's Religion \& Public Life Project, “ The Future Of the Global Muslim Population: Projection for 2010-2013, "Pew Research Center, January 2011, 13. 
Syaifuddin, H., Salis, R., \& Mafrudlo, A. M., Konstruksi Sufistik Pendidikan Multikultural... 